\title{
False recognition production indexes in Spanish for 60 DRM lists with three critical words
}

\author{
Maria Soledad Beato • Emiliano Díez
}

Published online: 7 February 2011

(C) Psychonomic Society, Inc. 2011

\begin{abstract}
A normative study was conducted using the Deese/Roediger-McDermott paradigm (DRM) to obtain false recognition for 60 six-word lists in Spanish, designed with a completely new methodology. For the first time, lists included words (e.g., bridal, newlyweds, bond, commitment, couple, to marry) simultaneously associated with three critical words (e.g., love, wedding, marriage). Backward associative strength between lists and critical words was taken into account when creating the lists. The results showed that all lists produced false recognition. Moreover, some lists had a high false recognition rate (e.g., 65\%; jail, inmate, prison: bars, prisoner, cell, offender, penitentiary, imprisonment). This is an aspect of special interest for those DRM experiments that, for example, record brain electrical activity. This type of list will enable researchers to raise the signal-to-noise ratio in false recognition event-related potential studies as they increase the number of critical trials per list, and it will be especially useful for the design of future research.
\end{abstract}

Keywords False memory $\cdot$ False recognition $\cdot$ DRM paradigm $\cdot$ Backward associative strength

This research was supported by grants from two Spanish funding agencies: Junta de Castilla y León (Proyecto SA007A08) and Ministerio de Educación y Ciencia (Proyecto PSI2008-05607). The authors express their gratitude to Gregory Francis and three anonymous reviewers for their helpful comments and suggestions during the review process.

M. S. Beato $(\bowtie) \cdot$ E. Díez

Faculty of Psychology, University of Salamanca,

Avda. de la Merced 109-131,

37005, Salamanca, Spain

e-mail:msol@usal.es
One of the most used procedures to produce associative memory illusions has been the Deese/Roediger-McDermott (DRM) paradigm (Deese, 1959; Roediger \& McDermott, 1995). In the original DRM paradigm, participants study word lists (e.g., invitation, celebration, fun, dance, etc.) that are highly associated, according to free association norms, with a nonpresented critical word (e.g., party). After each list presentation, an immediate free recall test is administered, and sometimes, after all the lists have been presented, a final recognition test is also given. Using this procedure, true recall and recognition of the studied words is observed at the same time as false recall and false recognition of the nonpresented critical words. This paradigm has shown its usefulness, and it is still being employed nowadays because it is a simple yet powerful technique to produce false memories in laboratory settings (Carneiro \& Fernandez, 2010; Fenn, Gallo, Margoliash, Roediger, \& Nusbaum, 2009; Gallo, 2006; Kim \& Cabeza, 2007; Unsworth \& Brewer, 2010).

The DRM paradigm has also been used in event-related potential (ERP) experiments, in which behavioral indices are complemented with recordings of the electroencephalographic activity related to responses to studied, critical, or distractor words in a recognition test. Usually, in DRM/ ERP experiments, researchers aim to observe differential brain activity associated with true and false recognition.

One of the main problems encountered in DRM/ERP experiments is the poor signal-to-noise $(\mathrm{S} / \mathrm{N})$ ratio of critical trials. This $\mathrm{S} / \mathrm{N}$ ratio is a measure of the quality of the signal and it increases as a function of the square root of the number of trials (Luck, 2005). For example, four times as many trials are needed to double the $\mathrm{S} / \mathrm{N}$ ratio of a measure. In the DRM paradigm, commonly a small number of lists are presented. As a consequence, the number of critical words tested is also necessarily small, and this could be a problem because not enough critical false alarms are obtained to allow a robust statistical analysis of brain electrical activity 
associated with false recognition responses. In an attempt to solve this problem, most DRM/ERP studies include some kind of variation on the standard procedure to increase the number of critical trials per study list. For example, instead of using a single critical word per list, some researchers have used two (Chen, Li, Westerberg, \& Tzeng, 2008; Israel \& Schacter, 1997; Miller, Baratta, Wynween, \& Rosenfeld, 2001; Nessler \& Mecklinger, 2003), three (Wiese \& Daum, 2006), four (Curran, Schacter, Johnson, \& Spinks, 2001; Fabiani, Stadler, \& Wessels, 2000), five (Nessler, Mecklinger, \& Penney, 2001), eight (Nessler, Friedman, \& Bersick, 2004), or even nine (Goldmann et al., 2003) critical words per study list.

Different strategies have been used to increase the number of critical words. First, Goldmann et al. (2003) employed items from semantic categories (e.g., dogs, cars). They included the same number of studied and critical trials (nine words) per study list in the final recognition test, following a procedure similar to that described by Nessler et al. (2001) (five studied words and five critical words for each list). In Nessler et al.'s study, to increase the probability of critical false alarms, these words were always taken from the seven most typical exemplars of each semantic category.

Secondly, other studies have used as nonpresented critical words the critical word itself, plus some of the first associated words of the list. Using this procedure, Wiese and Daum (2006) included three critical words (a critical word and the two most highly associated words of each list) to record brain electrical activity related to true and false recognition. Employing the same strategy, Curran et al. (2001) increased to four the number of critical words for each study list (a critical word and the three most highly associated words).

A modification of DRM list construction was also used in Miller et al. (2001) to analyze whether the latency of the evoked potential P300 allows true and false recognition to be differentiated. More specifically, these authors used 25 fourteen-word lists highly associated with a nonpresented critical word. To increase the number of critical words, a word with a strong semantic association (the first or second word on the list) was not included in the study stage, and was used, together with the critical word itself, as a critical word for that list, following the same procedure employed by Israel and Schacter (1997).

All these types of studies have ignored that the original DRM lists were designed so that the elements of the list were associated with the critical word. Increasing the number of critical words in this way does not necessarily imply that there exists an association between the elements of the list and the new critical items. For this reason, it seems logical to think that the strategies followed to increase the number of critical words, and therefore to increase the probability of critical false alarms, are not the most appropriate ones. A DRM list should include critical words (one, two, or more) associatively related to all words of the lists. In both DRM false memory and DRM/ERP studies, lists should be used that meet these criteria; however, until now, when DRM lists have been employed with two or more critical words, these criteria has not been met in any research.

In this article, an original normative study for 60 DRM lists in Spanish was conducted. First, the lists were created with a completely new method. For the first time, they included six words simultaneously associated with three critical words in each list. So far, all DRM normative studies in Spanish (Alonso, Fernandez, Díez, \& Beato, 2004; Anastasi, De Leon, \& Rhodes, 2005), English (Stadler, Roediger, \& McDermott, 1999), and other languages (e.g., Hamajima, 2000; Stein, Feix, \& Rohenkohl, 2006) have used a single critical word per list.

Moreover, since previous research has shown that backward association strength (BAS) seems to be closely related to the production of false memories (Gallo, \& Roediger, 2002; Howe, Wimmer, \& Blease, 2009; Howe, Wimmer, Gagnon, \& Plumpton, 2009; McEvoy, Nelson, \& Komatsu, 1999; Roediger, Watson, McDermott, \& Gallo, 2001), the lists were drawn up based on the BAS values between the words on the list and the critical words. Later, false recognition levels of the critical words were determined empirically using the DRM procedure (see, e.g., Gallo \& Roediger, 2002, Exp. 3). The standard free recall task was not included after each study list to avoid its effect on the recognition task (Gallo, \& Roediger, 2002, Exps. 1 and 2; Roediger \& McDermott, 1995; Stadler et al., 1999).

\section{Method}

Participants

The sample comprised 144 university students whose native language was Spanish. Participants' ages ranged from 21 to 45 years $(M=22.77, S D=2.56)$, and $92.36 \%$ were women. Participation was voluntary and not remunerated.

\section{Materials}

A total of 60 six-word lists were used, composed of the strongest backward associates to three critical words. The associated words of each list and their corresponding 
critical words, along with each item's approximate English translation, are included in Appendix A. The BAS values for each critical word were calculated with the sum of associative strength of its six associated words, and the associative strengths of the lists were considered as the sum of the BAS values for the three critical words (Robinson \& Roediger, 1997).

To build these word lists, free association norms for 4,051 Spanish words were used (Fernández, Díez, \& Alonso, 2009). A Perl computer program was designed to run through 195,187 cue-target word pairs produced by more than 1 participant available in the free association norms, in order to select groups of six or more elements that produced the same three words. From the output generated by the program $(85,410$ sets $)$, it was possible to select groups of six words that had the characteristic of producing triads of words as free association responses (backward associative strength).

The definitive set of word lists was selected by applying the five criteria below:

Criterion 1 None of the critical words could be an associated word in the same list.

Criterion 2 The words on the list had to surpass a minimum BAS threshold with respect to each of the critical words. Specifically, no words were used with an associative strength lower than 0.01 .

Criterion 3 The associative strength of each word of the list consisted of the sum of the BAS values of that word with respect to all three critical words. No words were used with a BAS sum lower than 0.20 .

Criterion 4 The BAS value for each critical word consisted of the sum of the associative strength of its six associated words. Lists in which any of the critical words had a BAS sum lower than 0.20 were not selected.

Criterion 5 Within each list, the six words with the highest associative strength were selectedthat is, those words that, fulfilling the above criteria, showed the highest backward associative strength with the three critical words.

The 360 associated words had lengths ranging from 3 to 14 characters $(M=6.76, S D=1.97)$ and showed an associative strength with the critical words between 0.01 and $0.86(M=0.14, S D=0.14)$. The 180 critical words had lengths ranging from 3 to 10 characters $(M=5.56$, $S D=1.49$ ). The BAS values for each critical word (sum of the associative strengths of its six associates) ranged from 0.20 to $2.34(M=0.83, S D=0.47)$. Finally, the 60 lists included in the study (sum of BAS values for the three critical words) showed total BAS values between 1.35 and $4.00(M=2.50, S D=0.52)$.

The words were arranged on the lists in decreasing order of their BAS with the critical words and were digitalized with a male voice.

For the recognition test, a response booklet was created including 180 words: 90 studied words, 45 critical words, and 45 unrelated distractors. All distractors were different from the associated and critical words. Therefore, six associated and three critical words per study list were included, as well as 45 new words from five associated word lists obtained from a previous Spanish DRM normative study (Alonso et al., 2004). In this way, the same number of studied and non-studied words (90 studied and 90 non-studied words) were included. The words presented in the recognition test were randomly placed in six different orders.

Procedure

The 60 lists were distributed in four groups of 15 lists. Within each group, it was confirmed that no associated or critical word was repeated. The order of presentation of the lists was random, and six different orders were created.

The experimental sessions were run in groups of 29-54 persons. At the beginning of the session, participants were informed that they would take part in an experiment about memory and math skills. The experiment consisted of hearing 15 six-word lists that they had to memorize and then responding to a memory test, whose nature was not specified. After the presentation of each list, they also had to quickly solve a set of simple arithmetic operations. They were given $1 \mathrm{~min}$ to do this, and it served as a distractor task.

Before the beginning of the study phase, participants listened to an example list to familiarize themselves with the voice and rhythm of the presentation: one word every 2 s. They then listened to the first list, followed by arithmetic operations, and then carried on successively until all 15 lists had been heard. Once they had finished the last page of arithmetic operations, participants received instructions for the final self-paced recognition test.

\section{Results and discussion}

Appendix A includes 60 six-word lists and their corresponding three critical words, with the associative strength values. Also, for each list several columns are 
included with the mean percentages of true and false recognition, as well as the percentage of false recognition for each critical word.

\section{True recognition}

Participants were very precise in their answers when recognizing the studied words, with true recognition occurring $74 \%$ of the time $(S D=9.51)$. This global level of true recognition was higher than those found in another normative study (i.e., 53\% in Alonso et al., 2004). Likewise, the percentage of false alarms for the unrelated distractors was very low (3\%), also in comparison with previous studies (e.g., 14\% in Alonso et al., 2004; 7\% in Gallo, \& Roediger, 2002, Exp. 1). The presentation of only six words in each study list could explain the high precision in true recognition as well as the low level of false alarms.

\section{False recognition}

All lists produced false recognition, although a detailed analysis of the results showed wide differences in the false recognition for each list (the mean percentages of the three critical words). Some lists yielded very low levels of false recognition-for example, animal, cat, lion list (feline, ferocity, paw, veterinary, claw, and hyena) (4\%)-whereas other lists produced high levels of false recognition-for example, jail, inmate, prison list (bars, prisoner, cell, offender, penitentiary, and imprisonment) (65\%). Overall, the mean false recognition for the 60 three-critical-word lists was $27 \%(S D=12.77)$.

False recognition for individual critical words also presented a high variability. More precisely, none of the participants incorrectly recognized the critical words pain, water, cleaning, salad, green, and death, whereas the critical word prison showed the highest false recognition (84\%).

These results are consistent with previous normative studies in Spanish and English (e.g., Alonso et al., 2004; Anastasi et al., 2005; Stadler et al., 1999) that displayed high variability in false recognition rates.

\section{Conclusions}

The main objective of this research was to conduct a normative study to empirically examine false recognition for 60 DRM lists in Spanish with three critical words each. Lists were designed with a completely new methodology, in the sense that the six words included in each list showed, at the same time, an associative relation with the three critical words.

The results demonstrate that DRM lists with associated words related simultaneously to three critical words produced false recognition. That is, the new method of construction of DRM lists used in this work was effective. Despite this being so, it should also be noted that false recognition ranged between $4 \%$ and $65 \%$. This fairly wide variability has been common in other, earlier normative studies for DRM lists. For example, in Anastasi et al. (2005), false recognition ranged from $26 \%$ to $100 \%$, and in Stadler et al. (1999) from $27 \%$ to $84 \%$, although the false recognition percentage may be influenced by a previous recall test in these studies.

Previous research has confirmed that false memories in the DRM paradigm are, at least in part, determined by the BAS between list words and critical words (e.g., Howe, Wimmer, \& Blease, 2009; McEvoy et al., 1999; Roediger et al., 2001). However, although our lists included the associated words with the highest BAS values, the analysis of false recognition showed a wide variability in the effectiveness of the 60 lists in eliciting false recognition, a variability for which several explanations have been offered (Brainerd \& Wright, 2005; Brainerd, Yang, Reyna, Howe, \& Mills, 2008; Gallo \& Roediger, 2002; McEvoy et al., 1999; Park, Shobe, \& Kihlstrom, 2005; Roediger et al., 2001).

The DRM paradigm is currently one of the most frequently used laboratory procedures in the memory distortion research area. The materials and normative data derived from this research could be especially useful for studying associative illusions of memory by means of electroencephalographic techniques, since they will facilitate an increase in the poor $\mathrm{S} / \mathrm{N}$ ratio reached with standard one-critical-word DRM lists. By tripling the number of critical trials in which false recognition can occur, noise levels can be reduced, thus enabling more robust statistical analysis of the brain electrical activity associated with false memories.

Finally, the contributions of this article are, first, the DRM normative study in itself, which allows for a selection from a pool of lists with known levels of false recognition to be used in many different Spanish-speaking countries. Second, it has been demonstrated that this new method of construction of DRM lists was effective at producing false recognition. This methodology may be used in future research that seeks to increase the number of critical words per list with a strategy different from the one most commonly employed - that is, the use of list words or members of categories - where the association levels are generally unknown. 


\section{Appendix A}

Table 1 The 60 six-word lists with three critical words, the sum of the associative strength of the six list words with respect to the three critical words, the mean percentages of true and false recognition, and the false recognition percentage for each critical word

CRITICAL: associated words (approximated English translation)

\begin{tabular}{llllll}
$\begin{array}{l}\text { Associative } \\
\text { strength }\end{array}$ & TR & FR list & FR Crit1 & FR Crit2 & FR Crit3 \\
\hline 3.089 & 67.71 & 64.58 & 43.75 & 65.63 & 84.38 \\
2.580 & 73.56 & 50.57 & 10.34 & 65.52 & 75.86 \\
& & & & & \\
2.825 & 66.67 & 50.00 & 37.50 & 37.50 & 75.00 \\
2.775 & 60.34 & 49.43 & 20.69 & 65.52 & 62.07 \\
1.853 & 87.93 & 48.28 & 51.72 & 62.07 & 31.03 \\
& & & & & \\
2.287 & 76.44 & 48.28 & 51.72 & 10.34 & 82.76 \\
3.014 & 66.36 & 45.06 & 35.19 & 64.81 & 35.19 \\
3.056 & 72.53 & 43.83 & 48.15 & 35.19 & 48.15
\end{tabular}

List 1 CÁRCEL / PRESO / PRISIÓN: rejas, prisionero, celda, reo, presidio, reclusión (JAIL / INMATE / PRISON: bars, prisoner, cell, offender, penitentiary, imprisonment)

List 2 AMOR / BODA / MATRIMONIO: nupcial, novios, enlace, $\quad 2.580$ compromiso, pareja, casar (LOVE / WEDDING / MARRIAGE: bridal, newlyweds, bond, commitment, couple, to marry)

List 3 MIEDO / PÁNICO / TEMOR: terror, pavor, horror,
aterrorizado, susto, temeroso (FEAR / PANIC / AWE: terror, dread, horror, terrified, scare, fearful)

List 4 HORROR / MIEDO / TERROR: pavor, temor, pánico, espanto, susto, pesadilla (HORROR / FEAR / TERROR: dread, awe, panic, fright, scare, nightmare)

List 5 EJÉRCITO / MILITAR / SOLDADO: mili, coronel, cuartel, infantería, general, legión (ARMY / MILITARY / SOLDIER: military service, colonel, barracks, infantry, general, legion)

List 6 DORMIR / NOCHE / SUEÑO: cama, pesadilla, camisón, descansar, soñar, cansancio (TO SLEEP / NIGHT / DREAM: bed, nightmare, nightdress, to rest, to dream, tiredness)

List 7 DINERO / SUELDO / TRABAJO: monedero, cobrar, salario, empleo, jornal, paga (MONEY / WAGE / WORK: purse, to charge, salary, employment, day's pay, pay)

List 8 IGLESIA / BODA / CURA: párroco, ceremonia, sacerdote, capellán, capilla, casar (CHURCH / WEDDING /

CLERGYMAN: parish priest, ceremony, priest, chaplain, chapel, to marry)

List 9 IGLESIA / CURA / MONJE: clérigo, sotana, sacerdote, fraile, monasterio, monja (CHURCH / CLERGYMAN / MONK: cleric, cassock, priest, friar, monastery, nun)

List 10 ALEGRÍA / FELICIDAD / SONRISA: júbilo, risa, simpatía, optimismo, reír, carcajada (JOY / HAPPINESS / SMILE: jubilation, laughter, sympathy, optimism, to laugh, laugh)

List 11 CATARRO / ENFERMEDAD / GRIPE: contagio, virus, constipado, tos, resfriado, estornudo (CATARRH / DISEASE / FLU: contagion, virus, to have a cold, cough, cold, sneeze)

List 12 AMOR / NOVIO / PAREJA: pretendiente, cariño, relación, enamorado, besar, caricia (LOVE / BOYFRIEND / COUPLE: suitor, fondness, relationship, in love, to kiss, caress)

List 13 GAFAS / VER / VISTA: óptica, ojo, lentillas, prismáticos, lupas, visión (GLASSES / TO SEE / SIGHT: optics, eye, contact lenses, binoculars, magnifiers, vision)

List 14 ALEGRÍA / FELICIDAD / RISA: carcajada, humor, sonrisa, gracia, diversión, simpatía (JOY / HAPPINESS /

LAUGHTER: laugh, humor, smile, jocularity, fun, sympathy)

List 15 ROPA / TRAJE / VESTIDO: modista, percha, vestir, tela, elegante, tejido (CLOTHING / COSTUME / DRESS: dressmaker, hanger, to dress, cloth, elegant, fabric)

List 16 GAFAS / OJO / VISTA: ocular, óptica, miopía, oculista, lentillas, visión (GLASSES / EYE / SIGHT: ocular, optics, myopia, oculist, contact lenses, vision)

List 17 DIVERSIÓN / FIESTA / MÚSICA: guateque, verbena, festival, baile, concierto, discoteca (FUN / PARTY / MUSIC: bash, open-air dance, festival, dance, concert, disco)

List 18 CAMA / DORMIR / NOCHE: mesilla, descansar, sueño, camisón, descanso, soñar (BED / TO SLEEP / NIGHT: bedside table, to rest, dream, nightdress, rest, to dream)

2.965

1.915

2.310

2.320

1.900

2.073
72.41

74.14

$$
84.8
$$

74.6

39.51

43.68

17.24

44.83

68.97

4.14

43.68

51.72

27.59

51.72

4.88

41.36

66.67

24.07

33.33

75.

$$
75.0
$$

60.9

60.9

$$
59.2
$$

59.20

34.48

39.51

31.4

22.22

64.81

$$
84.48
$$

4.48

32.18

81.6

31.03

51.8

24.07

42.59

$36.78 \quad 34.48$

10.34

65.52

$48-3.45$

44.83

55.17

$\begin{array}{lllll}72.53 & 30.25 & 37.04 & 50.00 & 3.70\end{array}$


Table 1 (continued)

CRITICAL: associated words (approximated English translation) Associative TR FR list $\quad$ FR Crit1 FR Crit2 FR Crit3 strength

List 19 AMIGO / AMOR / CARIÑO: afecto, abrazo, aprecio, novio, amistad, fiel (FRIEND / LOVE / FONDNESS: affection, hug, esteem, boyfriend, friendship, faithful)

List 20 CASA / EDIFICIO / PISO: vivienda, portal, fachada, arquitecto, ático, viga (HOME / BUILDING / FLOOR: dwelling, doorway, facade, architect, attic, beam)

List 21 CAMA / DESCANSO / DORMIR: almohada, lecho, sueño, sábana, sofá, cansancio (BED / REST / TO SLEEP: pillow, resting place, dream, sheet, sofa, tiredness)

List 22 DOLOR / HERIDA / SANGRE: daño, rasguño, corte, pinchazo, ampolla, cicatriz (PAIN / INJURY / BLOOD: damage, scratch, cut, prick, blister, scar)

List 23 BOMBA / FUEGO / GUERRA: explosión, cañón, misil, dinamita, destrucción, barricada (BOMB / FIRE / WAR: explosion, cannon, missile, dynamite, destruction, barricade)

List 24 DOLOR / MUERTE / TRISTEZA: fallecimiento, pésame, entierro, pena, agonía, funeral (PAIN / DEATH / SADNESS: demise, condolence, burial, sorrow, agony, funeral)

List 25 IGLESIA / CURA / MONJA: sotana, convento, sacerdote, religiosa, católica, fraile (CHURCH / CLERGYMAN / NUN: cassock, convent, priest, religious woman, Catholic, friar)

List 26 ABRIGO / CALOR / FRÍO: bufanda, manta, invierno, jersey, escalofrío, gabardina (COAT / HEAT / COLD: scarf, blanket, winter, jersey, chill, raincoat)

List 27 CIUDAD / LUGAR / PUEBLO: villa, municipio, localidad, comarca, localización, región (CITY / PLACE / VILLAGE: town, municipality, locality, district, location, region)

List 28 FÚTBOL / JUEGO / PELOTA: balón, deportes, béisbol, baloncesto, bola, tenis (FOOTBALL / GAME / GOLF or TENNIS BALL: ball, sports, baseball, basketball, pellet, tennis)

List 29 ACTOR / PELÍCULA / TEATRO: escena, interpretación, escenario, actriz, intérprete, actuar (ACTOR / FILM / THEATRE: scene, interpretation, stage, actress, interpreter, to act)

List 30 ALCOHOL / BEBIDA / FIESTA: vodka, juerga, ron, licor, borracho, borrachera (ALCOHOL / DRINK / PARTY: vodka, spree, rum, liqueur, drunk, drunkenness)

List 31 DINERO / REY / RIQUEZA: poderoso, palacio, aristocracia, lujo, nobleza, poder (MONEY / KING / WEALTH: powerful, palace, aristocracy, luxury, nobility, power)

List 32 CIGARRO / HUMO / TABACO: cenicero, ceniza, puro, fumar, 2.140 pipa, mechero (CIGARETTE / SMOKE / TOBACCO: ashtray, ash, cigar, to smoke, pipe, lighter)

List 33 LUZ / NOCHE / SOL: día, luna, amanecer, sombra, estrella, atardecer (LIGHT / NIGHT / SUN: day, moon, dawn, shadow, star, dusk)

List 34 ARMA / DISPARO / PISTOLA: revólver, bala, rifle, fusil, metralleta, escopeta (WEAPON / SHOT / PISTOL: revolver, bullet, rifle, handgun, machine gun, shotgun)

List 35 ARMA / GUERRA / PISTOLA: metralleta, balas, munición, fusil, rifle, disparo (WEAPON / WAR / PISTOL: machine gun, bullets, ammunition, handgun, rifle, shot)

List 36 AGUA / BARCO / MAR: navegación, puerto, navío, marinero, flota, océano (WATER / BOAT / SEA: navigation, port, ship, sailor, fleet, ocean)

List 37 ARMA / MUERTE / PISTOLA: balas, disparo, revólver, rifle, fusil, metralleta (WEAPON / DEATH / PISTOL: bullets, shot, revolver, rifle, handgun, machine gun)

List 38 COLONIA / FLOR / OLOR: jazmín, perfume, aroma, fragancia, esencia, violeta (COLOGNE / FLOWER / SMELL: jasmine, perfume, aroma, fragrance, essence, violet)

\begin{tabular}{|c|c|c|c|c|c|}
\hline 2.245 & 86.21 & 29.89 & 34.48 & 13.79 & 41.38 \\
\hline 2.299 & 66.67 & 29.89 & 27.59 & 44.83 & 17.24 \\
\hline 2.441 & 68.75 & 29.17 & 25.00 & 31.25 & 31.25 \\
\hline 2.325 & 66.67 & 29.01 & 16.67 & 61.11 & 9.26 \\
\hline 2.090 & 72.41 & 28.74 & 62.07 & 6.90 & 17.24 \\
\hline 3.028 & 82.29 & 28.13 & 25.00 & 34.38 & 25.00 \\
\hline 2.980 & 71.88 & 27.08 & 9.38 & 21.88 & 50.00 \\
\hline 2.506 & 95.83 & 27.08 & 40.63 & 6.25 & 34.38 \\
\hline 1.918 & 89.08 & 26.44 & 37.93 & 6.90 & 34.48 \\
\hline 1.840 & 86.21 & 26.44 & 13.79 & 13.79 & 51.72 \\
\hline 2.710 & 70.11 & 26.44 & 13.79 & 17.24 & 48.28 \\
\hline 2.295 & 79.17 & 26.04 & 34.38 & 15.63 & 28.13 \\
\hline 1.345 & 75.86 & 25.29 & 6.90 & 24.14 & 44.83 \\
\hline 2.140 & 86.21 & 25.29 & 24.14 & 31.03 & 20.69 \\
\hline 2.329 & 68.39 & 25.29 & 13.79 & 41.38 & 20.69 \\
\hline 2.100 & 81.77 & 25.00 & 15.63 & 12.50 & 46.88 \\
\hline 2.675 & 74.38 & 24.07 & 40.74 & 18.52 & 12.96 \\
\hline 3.708 & 66.67 & 22.99 & 6.90 & 44.83 & 17.24 \\
\hline 2.340 & 72.41 & 22.99 & 24.14 & 0.00 & 44.83 \\
\hline 2.500 & 94.83 & 22.99 & 31.03 & 13.79 & 24.14 \\
\hline
\end{tabular}


Table 1 (continued)

CRITICAL: associated words (approximated English translation)
Associative TR FR list $\quad$ FR Crit1 $\quad$ FR Crit2 FR Crit3

strength

\begin{tabular}{|c|c|c|c|c|c|}
\hline 3.225 & 71.88 & 21.88 & 0.00 & 34.38 & 31.25 \\
\hline 3.159 & 57.47 & 21.84 & 3.45 & 10.34 & 51.72 \\
\hline 3.085 & 76.04 & 20.83 & 6.25 & 9.38 & 46.88 \\
\hline 2.082 & 79.89 & 20.69 & 0.00 & 31.03 & 31.03 \\
\hline 2.980 & 95.68 & 18.52 & 22.22 & 25.93 & 7.41 \\
\hline 1.988 & 66.67 & 18.39 & 37.93 & 17.24 & 0.00 \\
\hline 2.467 & 75.31 & 17.90 & 7.41 & 33.33 & 12.96 \\
\hline 1.984 & 79.69 & 17.71 & 15.63 & 31.25 & 6.25 \\
\hline 3.235 & 81.61 & 17.24 & 6.90 & 24.14 & 20.69 \\
\hline 1.909 & 62.64 & 17.24 & 13.79 & 20.69 & 17.24 \\
\hline 2.768 & 77.47 & 16.67 & 9.26 & 33.33 & 7.41 \\
\hline 3.022 & 69.79 & 16.67 & 12.50 & 12.50 & 25.00 \\
\hline 1.749 & 68.21 & 16.05 & 22.22 & 12.96 & 12.96 \\
\hline 2.276 & 46.35 & 14.58 & 18.75 & 6.25 & 18.75 \\
\hline 2.696 & 65.43 & 13.58 & 7.41 & 24.07 & 9.26 \\
\hline 3.995 & 77.59 & 11.49 & 6.90 & 24.14 & 3.45 \\
\hline 1.874 & 73.46 & 11.11 & 3.70 & 9.26 & 20.37 \\
\hline 3.130 & 76.85 & 10.49 & 1.85 & 25.93 & 3.70 \\
\hline 2.898 & 64.06 & 10.42 & 15.63 & 3.13 & 12.50 \\
\hline 1.918 & 77.01 & 6.90 & 6.90 & 3.45 & 10.34 \\
\hline
\end{tabular}

List 39 AGUA / MAR / PLAYA: olas, orilla, bahía, costa, nadar, puerto (WATER / SEA / BEACH: waves, shore, bay, coast, to swim, port)

List 40 AGUA / MAR / RÍO: cauce, pez, orilla, lago, barca, bahía (WATER / SEA / RIVER: riverbed, fish, shore, lake, boat, bay)

List 41 CINE / PELÍCULA / TEATRO: escena, estreno, escenario, trama, actor, ficción (CINEMA / FILM / THEATRE: scene, premiere, stage, plot, actor, fiction)

List 42 DOLOR / ENFERMEDAD / GRIPE: contagio, anginas, constipado, vacuna, fiebre, resfriado (PAIN / DISEASE / FLU: contagion, tonsillitis, to have a cold, vaccine, fever, cold)

List 43 BAILE / FIESTA / MÚSICA: verbena, guateque, tocadiscos, disco, discoteca, concierto (DANCE / PARTY / MUSIC: open-air dance, bash, record-player, record, disco, concert)

List 44 BAÑO / DUCHA / LIMPIEZA: gel, toalla, bañera, servicio, lavabo, jabón (BATHROOM / SHOWER / CLEANING: gel, towel, bath, toilet, sink, soap)

List 45 FLOR / PLANTA / ÁRBOL: raíz, tallo, semilla, laurel, brote, hojas (FLOWER / PLANT / TREE: root, stem, seed, laurel, shoot, leaves)

List 46 CIGARRO / FUMAR / TABACO: cenicero, pipa, humo, mechero, puro, pulmones (CIGARETTE / TO SMOKE / TOBACCO: ashtray, pipe, smoke, lighter, cigar, lungs)

List 47 FRÍO / HIELO / NIEVE: glaciar, Antártida, iceberg, pingüino, iglú, esquimal (COLD / ICE / SNOW: glacier, Antarctica, iceberg, penguin, igloo, Eskimo)

List 48 ALCOHOL / BEBIDA / VINO: copa, licor, borracho, botella, sobriedad, litro (ALCOHOL / DRINK / WINE: glass, liqueur, drunk, bottle, soberness, liter)

List 49 CHOCOLATE / DULCE / FRESA: batido, sabor, caramelo, pastel, mermelada, tarta (CHOCOLATE / SWEET / STRAWBERRY: milk shake, flavor, candy, pie, jam, cake)

List 50 FLOR / OLOR / ROSA: jazmín, clavel, amapola, tulipán, aroma, rosal (FLOWER / SMELL / ROSE: jasmine, carnation, poppy, tulip, aroma, rosebush)

List 51 ALCOHOL / CERVEZA / VINO: taberna, litro, borracho, botella, beber, borrachera (ALCOHOL / BEER / WINE: tavern, liter, drunk, bottle, to drink, drunkenness)

List 52 EJÉRCITO / GUERRA / MILITAR: batallón, soldado, infantería, milicia, coronel, regimiento (ARMY / WAR / MILITARY: battalion, soldier, infantry, militia, colonel, regiment)

List 53 CASA / CIUDAD / PUEBLO: rural, urbe, villa, urbana, municipio, habitante (HOME / CITY / VILLAGE: rural, metropolis, town, urban, municipality, inhabitant)

List 54 ANIMAL / GATO / PERRO: maullido, mascota, maullar, pulgas, rabo, veterinaria (ANIMAL / CAT / DOG: miaow, pet, to meow, fleas, tail, veterinary)

List 55 AIRE / CIELO / VOLAR: globo, cometa, avión, helicóptero, pájaro, águila (AIR / SKY / TO FLY: balloon, kite, plane, helicopter, bird, eagle)

List 56 CALOR / FRÍO / INVIERNO: estufa, abrigo, manta, bufanda, escalofrío, gorro (HEAT / COLD / WINTER: stove, coat, blanket, scarf, chill, bonnet)

List 57 BOSQUE / VERDE / ÁRBOL: pino, prado, frondoso, nogal, vegetación, abeto (FOREST / GREEN / TREE: pine, meadow, leafy, walnut, vegetation, fir)

List 58 COMIDA / VERDE / VERDURA: alcachofa, coliflor, rábano, 1.918 acelgas, pimiento, apio (FOOD / GREEN / VEGETABLE: artichoke, cauliflower, radish, Swiss chard, pepper, celery) 
Table 1 (continued)

CRITICAL: associated words (approximated English translation) $\begin{array}{llllll}\text { Associative } & \text { TR } & \text { FR list } & \text { FR Crit1 } & \text { FR Crit2 } & \text { FR Crit3 }\end{array}$ strength

List 59 ENSALADA / VERDE / VERDURA: lechuga, alcachofa,

2.006

$70.69 \quad 5.75$

0.00

0.00

17.24 pimiento, tomate, coliflor, rábano (SALAD / GREEN / VEGETABLE: lettuce, artichoke, pepper, tomato, cauliflower, radish)

List 60 ANIMAL / GATO / LEÓN: felino, fiereza, zarpa, veterinaria, garra, hiena (ANIMAL / CAT / LION: feline, ferocity, paw, 2.120 $\begin{array}{lll}78.65 & 4.17 \quad 3.13\end{array}$ 6.25 3.13 veterinary, claw, hyena)

Note: TR, Mean percentage of true recognition per list; FR list, Mean percentage of false recognition per list; FR Crit1, False recognition percentage of first critical word; FR Crit2, False recognition percentage of second critical word; FR Crit3, False recognition percentage of third critical word.

\section{References}

Alonso, M. A., Fernandez, A., Díez, E., \& Beato, M. S. (2004). Índices de producción de falso recuerdo y falso reconocimiento para 55 listas de palabras en castellano. Psicothema, 16, 357-362.

Anastasi, J. S., De Leon, A., \& Rhodes, M. G. (2005). Normative data for semantically associated Spanish word lists that create false memories. Behavior Research Methods, 37, 631-637.

Brainerd, C. J., \& Wright, R. (2005). Forward associative strength, backward associative strength, and the false memory illusion. Journal of Experimental Psychology. Learning, Memory, and Cognition, 31, 554-567. doi:10.1037/0278-7393.31.3.554

Brainerd, C. J., Yang, Y., Reyna, V. F., Howe, M. L., \& Mills, B. A. (2008). Semantic processing in "associative" false memory. Psychonomic Bulletin \& Review, 15, 1035-1053. doi:10.3758/ PBR.15.6.1035

Carneiro, P., \& Fernandez, A. (2010). Age differences in the rejection of false memories: The effects of giving warning instructions and slowing the presentation rate. Journal of Experimental Child Psychology, 105, 81-97.

Chen, J. C. W., Li, W., Westerberg, C. E., \& Tzeng, O. J. L. (2008). Test-item sequence affects false memory formation: An eventrelated potential study. Neuroscience Letters, 431, 51-56. doi:10.1016/j.neulet.2007.11.020

Curran, T., Schacter, D. L., Johnson, M. K., \& Spinks, R. (2001). Brain potentials reflect behavioral differences in true and false recognition. Journal of Cognitive Neuroscience, 13, 201-216.

Deese, J. (1959). On the prediction of occurrence of certain verbal intrusions in free recall. Journal of Experimental Psychology, 58, 17-22.

Fabiani, M., Stadler, M. A., \& Wessels, P. M. (2000). True but not false memories produce a sensory signature in human lateralized brain potentials. Journal of Cognitive Neuroscience, 12, 941949. doi:10.1162/08989290051137486

Fenn, K. M., Gallo, D. A., Margoliash, D., Roediger, H. L., III, \& Nusbaum, H. C. (2009). Reduced false memory after sleep. Learning \& Memory, 16, 509-513. doi:10.1101/lm.1500808

Fernández, A., Díez, E. \& Alonso, M. A. (2009). Normas de asociación libre en castellano [Online database]. Retrieved from www.usal.es/gimc, July 15.

Gallo, D. A. (2006). Associative illusions of memory: False memory research in DRM and related tasks. New York: Psychology Press.

Gallo, D. A., Roediger, H. L., \& Roediger, H. L., III. (2002). Variability among word lists in eliciting memory illusions: Evidence for associative activation and monitoring. Journal of Memory and Language, 47, 469-497.

Goldmann, R. E., Sullivan, A. L., Droller, D. B. J., Rugg, M. D., Curran, T., Holcomb, P. J., ... Budson, A. E. (2003). Late frontal brain potentials distinguish true and false recognition. NeuroReport, 14, 1717-1720. doi:10.1097/01.wnr.0000087908.78892.23

Hamajima, H. (2000). False memories created in laboratory experiments: The words lists in Japanese. Studies in Informatics and Sciences, Graduate School of Human Information, Nagoya University, 11, 175-193.

Howe, M. L., Wimmer, M. C., \& Blease, K. (2009). The role of associative strength in children's false memory illusions. Memory, 17, 8-16. doi:0.1080/09658210802438474

Howe, M. L., Wimmer, M. C., Gagnon, N., \& Plumpton, S. (2009). An associative-activation theory of children's and adults' memory illusions. Journal of Memory and Language, 60, 229251. doi:10.1016/j.jml.2008.10.002

Israel, L., \& Schacter, D. L. (1997). Pictorial encoding reduces false recognition of semantic associates. Psychonomic Bulletin \& Review, 4, 577-581.

Kim, H., \& Cabeza, R. (2007). Differential contributions or prefrontal, medial temporal, and sensory-perceptual regions to true and false memory formation. Cerebral Cortex, 17, 2143-2150. doi:10.1093/ cercor/bhl122

Luck, S. J. (2005). An introduction to the event-related potential technique. Cambridge: MIT Press.

McEvoy, C. L., Nelson, D. L., \& Komatsu, T. (1999). What is the connection between true and false memories? The differential roles of interitem associations in recall and recognition. Journal of Experimental Psychology. Learning, Memory, and Cognition, 25, 1177-1194. doi:10.1037/0278-7393.25.5.1177

Miller, A. R., Baratta, C., Wynween, Ch, \& Rosenfeld, J. P. (2001). P300 latency, but not amplitude or topography, distinguishes between true and false recognition. Journal of Experimental Psychology. Learning, Memory, and Cognition, 27, 354-361. doi: $10.1037 / 0278-7393.27 .2 .354$

Nessler, D., Friedman, D., \& Bersick, M. (2004). Classic and false memory designs: An electrophysiological comparison. Psychophysiology, 41, 679-687. doi:10.1111/j.1469-8986.2004. 00195.x

Nessler, D., \& Mecklinger, A. (2003). ERP correlates of true and false recognition after different retention delays: Stimulus- and response-related processes. Psychophysiology, 40, 146-159.

Nessler, D., Mecklinger, A., \& Penney, T. B. (2001). Event related brain potentials and illusory memories: The effects of differential encoding. Cognitive Brain Research, 10, 283-301.

Park, L., Shobe, K. K., \& Kihlstrom, J. F. (2005). Associative and categorical relations in the associative memory illusion. Psychological Science, 16, 792-797.

Robinson, K. J., \& Roediger, H. L., III. (1997). Associative processes in false recall and false recognition. Psychological Science, 8 , 231-237. 
Roediger, H. L., III, \& McDermott, K. B. (1995). Creating false memories: Remembering words not presented in lists. Journal of Experimental Psychology. Learning, Memory, and Cognition, 21, 803-814. doi:10.1037/0278-7393.21.4.803

Roediger, H. L., III, Watson, J. M., McDermott, K. B., \& Gallo, D. A. (2001). Factors that determine false recall: A multiple regression analysis. Psychonomic Bulletin \& Review, 8, 385-407.

Stadler, M. A., Roediger, H. L., III, \& McDermott, K. B. (1999). Norms for word lists that create false memories. Memory \& Cognition, 27, 494-500.
Stein, L. M., Feix, L. F., \& Rohenkohl, G. (2006). Avanços metodológicos no estudo das falsas memórias: Construção e normatização do procedimento de palavras associadas. Psicologia: Reflexão e Crítica, 19, 166-176.

Unsworth, N., \& Brewer, G. A. (2010). Individual differences in false recall: A latent variable analysis. Journal of Memory and Language, 62, 19-34. doi:10.1016/j.jml.2009.08.002

Wiese, H., \& Daum, I. (2006). Frontal positivity discriminates true from false recognition. Brain Research, 1075, 183-192. doi:10.1016/j.brainres.2005.12.117 